\title{
The Impact of Traditional Leadership on Voting Behavior at General Elections
}

\author{
M. Fachri Adnan*1, Hasbullah Malau², Heldo Aura ${ }^{3}$ \\ ${ }^{1,2}$ Universitas Negeri Padang, West Sumatra Indonesia \\ ${ }^{3}$ Member of General Election Commission Bukittinggi Town West Sumatra Indonesia
}

\begin{abstract}
This study discusses the impact of traditional leaders on voting behavior in a general election. Many studies have discussed factors yang that affect voting behavior in general elections. Nevertheless, most studies focus on the perception or evaluation of political leaders or characteristics of candidate leadership on voting behavior. This study is about the impact of traditional leadership on voting behavior in an election. Data were collected by questionnaire the community of Kurai in Bukittinggi Town West Sumatera and analyzed with simple regression. This study emphasizes improving the impact of traditional leadership on voting behavior at the general election. The purpose of the research is to investigate the effect of traditional leaders on voting behavior in a general election. Data were collected by questionnaire and analysis by descriptive and linear regression method. This study shows that traditional leader has a significant impact on the voting behavior of legislative general election.
\end{abstract}

Keywords: traditional leaders, voting behavior, general election

\section{INTRODUCTION}

$\mathrm{V}$ oting behavior is a momentary action of a citizen in determining his choice in an election. Even though this action is temporary, this voting behavior has captured the attention of social and political scientists to examine it from various perspectives, especially those related to the factors that influence voting behavior. Research on voting behavior in Slovakia shows that nationalism and the national economy affect voting preferences in elections (Stanley, 2011). Furthermore, the results of a study of the voting behavior of American Indians in the election of members of the United States Congress showed that Indian ethnic ties had a positive effect on voting behavior (Conner, 2014). Then the research of (Heath, Verniers, \& Kumar, 2015) shows that religious ties affect Voting behavior in India, Muslim voters in India. Furthermore, the study of Vizcaíno-González, PineiroChousa, \& López-Cabarcos, (2016), found that voting behavior is influenced by reputational damage. Another study concluded that the tone of the candidate's voice affects Voting behavior. (Tigue, Borak, O'Connor, Schandl, \& Feinberg, 2012), Another study examines perceptions of crisis and charismatic leadership in the 2004 United States presidential election. The results show that perceptions of crisis with the mediation of charismatic leadership harm voters against the incumbent George W. Bush. As for the challenger John Kerry, the perception of the crisis positively affects the voting behavior of the challenger John Kerry with the mediation of charismatic leadership (Williams, Pillai, Deptula, \& Lowe,
2012). So the perception of the crisis and the one mediated by the charismatic leadership can predict the outcome of the vote in the 2004 United States election.

Studies on voting behavior in general elections or regional head elections have also been frequently conducted in Indonesia. The study of electoral behavior in the 2005 West Sumatra gubernatorial election showed that the quality of candidates and campaign issues influenced voting behavior (Adnan, M. Fachri, 2013). Fitriyah's (2013) study on the election of regional heads in the Kudus Regency shows that economic factors and candidate figures affect voting behavior. Sugianto's (2020) study in the Kedabang Village in the 2019 presidential elections shows that candidates' community culture, political environment, social environment, and personality factors affect voting behavior. Another study shows that the dynamics of conflict in political parties affect voting behavior in elections (Fauzi, Mudzakir, \& Abdulrahim, 2019).

Several previous researchers have carried out studies on the influence of leadership on voting behavior. The study of Pillai, Williams, Lowe, \& Jung (2003) shows that voters can evaluate a candidate's personality and leadership abilities as a consideration in determining their choice in the United States presidential election. Research by (Liddle \& Mujani, 2007) also shows the influence of political party leadership on voting behavior in general elections in Indonesia.

Based on previous studies, it can be stated that the attention from previous researchers focused more on the influence of political party leadership on voting behavior and the influence of voting evaluation on candidate leadership in legislative elections and presidential vice-presidential elections. Thus no study examines the influence of traditional leadership on voting behavior in general elections or regional head elections.

This article discusses the influence of traditional leadership in the Kurai community of Bukittinggi Town voting behavior in legislative elections. The traditional leadership referred to in this article is the concept of leadership in Minangkabau culture, which consists of three elements, namely ninik mamak, as traditional leaders, alim ulama as Islamic religious leaders, and cadiak pandai as leaders from intellectual circles or scholars. These three elements of traditional leadership are still influential in the lives of the Kurai people who live in Bukittinggi Town. 


\section{LITERATUR REVIEW}

Approach to study Voting Behavior

Voting behavior is when voters select a particular party or candidate in a general election (Adnan, M. Fachri, 2013). Voting is one form of political participation that is very important in a liberal democracy because that the study of voting behavior is one of the fields of study in political science (Oxford Reference, 2021) Study on voting behavior is more focused on why someone decides to vote and what influences him to choose a party or a candidate at the certain elections. There are three common approaches in understanding voting behavior in elections: sociological approach, socio-psychological approach, and economic or rational approach (Antunes, 2010), (Adnan, M. Fachri, 2013). The sociological approach, also known as The Columbia School, was pioneered by a group of researchers from Columbia University that voting behavior is influenced by the social characteristics of citizens, among others. According to Hutchings \& Jefferson in Fisher, Justin et al. (Ed) (2018), social characteristics include; social status of citizens, racial and religious identity, and the area in which they live in urban or rural areas.

The socio-psychological approach is known as the Michigan School because researchers from Michigan University pioneered it. This approach emphasizes the attitude of individual voters and the identification of a particular political party. According to Michigan University group researchers (Hutchings, Vincent L \& Jefferson, Hakeen $\mathrm{J}$ in Fisher, Justin et al. (Ed) (2018), voters psychologically identify with particular political parties in line with their racial or ethnic identity, social class, or ethnicity. The social status they have. Identification of political parties can be seen as a long-term factor in a political system even though, at a particular time, voters choose other parties that are opposite in elections. Identification of a particular party is influential in determining the direct influence of one's choice in elections and indirect influence in determining their position in the voting.

The third approach is known as the rational approach, which is also known as the economic approach because it was pioneered by economist Anthony Down who belief that voters act rationally in determining the general election ((Adnan, M. Fachri, 2013), M. The fundamental assumption of this theory is that citizens act rationally in politics. This assumption has implications for voting behavior in general elections that every citizen makes his choice in a political party that he believes can provide benefits compared to other political parties. The key to the decision-making process in this approach is the voter's perception of the expected benefits after the general election.

\subsection{Leadership}

Leadership means the process of influencing and facilitating individuals and joint efforts to achieve a goal (Yukl, 2012)). Leadership can improve the performance of a team or organization by influencing the process of achieving performance. As stated by Wood, J. Luke \& Penrose, Rose (2013), and Wirawan (2013), leaders can be divided into informal and formal leaders. Informal leaders gain influence outside formal authority, titles, or organizational structures. The power or authority of informal leaders is given by their group based on trust, respect, influence, and support. Furthermore, Wirawan (2013) explains that informal leaders do not get formal organizational positions in the social system, but they influence social system members. Informal leaders include ulama, kyai, ninik mamak, experts in science, and cultural practitioners.

Formal leaders obtain authority based on power, such as special rights and responsibilities based on their position (Wood, J. Luke \& Penrose, Rose, 2013). Wirawan also (2013) said that a formal leader is a leader who has a formal status or position in an organization established based on state laws or regulations or company regulations. According to Wood, J. Luke \& Penrose, Rose (2013) power and authority of a formal leader are strengthened by his ability to provide rewards and punishments to individuals or groups he leads.

The role of leadership is significant in people's lives. This can be seen from the results of previous studies such as Latif, Mustanir, \& Irwan (2019) concluded that village government leadership affects community participation in village development planning. The study by Ratna Wijayanti (2016) shows the influence of Islamic leadership on employee performance. Nasution's (2017) results show that kyai, one of the informal religious leaders with the highest authority in traditional Javanese society, is an agent of social change and peace. Furthermore, the results of a study by Fitri \& Adnan (2019) show that ulama, as an element of traditional religious leadership in Minangkabau society, play a role in increasing community political participation in regional head elections. So based on the results of previous studies, it can be seen that formal leadership, such as the leadership of the village head, and informal leadership, such as kiyai and ulama, plays a significant role in people's lives.

In Minangkabau ethnic community, West Sumatra, Indonesia, the concept of traditional leadership consists of three elements; ninik mamak, traditional leadership, which comes from a custom element; alim ulama, a traditional leadership come from religious element; and cadiak pandai is a traditional leadership come from the intellectual element. The three-element of the traditional leadership of Minangkabau community culture is known as "tungku tigo sajarangan." The traditional leadership referred to in this study is the leadership of tungku tigo sajarangan, the Minangkabau ethnic community in West Sumatra, including the Kurai community of Bukittinggi Town. The pattern of the leadership of "tungku tigo sajarangan" is very close to Islamic religious that called "Adat Basandi Syarak, Syarak Basandi Kitabullah." This phrase means Islamic Religious is the foundation of the Minangkabau community's culture called Syarak, while Kitabullah, called Al-Qur'an, is the foundation of the Islam religion. Based on the results of the previous study, the leadership of tungku sajarangan impacts 
the development of the Nagari (Kurniawan, Adnan, \& Alhadi, 2020). Apart from that, the "tungku tigo sajarangan" leadership is relevant in overcoming ethnic marriage in Minangkabau society (Pratama, Bachriar, \& Fitriani, 2017).

Furthermore, the study results of Sesmiarni et al. (2018) show that the leadership of tungku tigo sajarangan is very relevant and in line with the Islamic education strategy as recommended in the Al Qur'an and Sunnah. The results of the study of Amri, Ramdani, Warsihna, \& Tae (2021) concluded that the concept of leadership, customs, and local wisdom originating from Minangkabau culture, known as the tungku tigo sajarangan, could be an alternative frame of mind and a suitable way in the field of education, one of which is for a university to become a world-class university. Meanwhile, the results of other studies indicate that the influence of the leadership of ulama as one element of traditional leadership in the Minangkabau community on political participation in the 2018 Padang Panjang Town head election (Fitri, Adnan \& Syamsir, 2019).

This study wants to analysis; "The influence of traditional leadership on the behavior of the Kurai people in the legislative general election in Bukittinggi Town, West Sumatra Indonesia. " The purpose of the study is to prove the influence of the traditional leadership on the voting behavior of Kurai people of Bukittinggi town in general elections.

\section{RESEARCH METHODE}

The research was conducted on the Kurai community as a native Bukittinggi at the legislative election by distributing questionnaires to the respondent. Data analysis of the Kurai people's voting behavior in the general election of the Kurai people of Bukittingi town, west Sumatra Indonesia. The research variable consists of obedience to traditional leadership as an independent variable (X). The measurement of the variable is the intensity of the Kurai indigenous people in following suggestions, instructions, advice from a community leader in legislative elections. Indicators of traditional leadership in Minangkabau society are ninik mamak, alim ulama, and cadiak pandai. Voting behavior in the study means the Kurai people who live around the City of Bukittinggi in legislative elections as the dependent variable (Y). In this study, voting behavior in general elections is defined as the Kurai community's intensity in supporting and voting for political parties in the general election for the legislative of Bukittinggi Town. Indicators of voting behavior are the intensity of voting participation in the general election campaign, participation in spreading and installing campaign attributes for political parties, the intensity of voters inviting others to participate in the campaigns of political parties that are supported, the intensity of voters inviting others to vote for legislative candidates or political parties to be elected, participation in providing financial assistance or other support for political parties to be elected, the intensity of participating in party meetings or meetings political.

The population of this study is voters of the Kurai community who live in the town of Bukittinggi, amounting to
$49 \%$ of the total number of Permanent Voters List (DPT) in the Bukittinggi Town was about 79,481, namely: $\mathrm{N}=49 \% \mathrm{x}$ $79,481=38,946$ inhabitants. The determination of this amount according to data from LKAAM Bukittinggi Town in 2013. The research sampling process uses a systematic random sample (Systematic Random Sampling) (Kareem, Oshungade, \& Oyeyemi, 2015) because the population is homogeneous. Systematic random sampling is a sampling method that randomly selects only the first element, while the subsequent elements are selected systematically according to a specific pattern. The number of research samples was determined based on the Slovin formula as quoted by Ridwan (2009), namely: $n=N /(N(d) 2+1$.) From this formula, the determined sample was 394 respondents.

The measurement of each indicator uses an ordinal scale with a value of 1 to 5 , namely S.S. = Strongly Agree given a value of 5, $\mathrm{S}=$ Agree given a value of $4, \mathrm{R}=$ Doubtful given a value of 3, T.S. = Disagree given a value of $2, \mathrm{STS}=$ Strongly Disagree Agree is given a value of 1. It transformed into an interval scale that strongly scales of $5.00-3.10$; being stated on a scale of $3.09-2.91$; weak stated on a scale of 2.90 $-1.00$

This study uses an ordinal measurement scale. This study conducts data entry and calculation of surveys with the SPSS22.0 program. Data analysis uses the Linear Regression Model with the Ordinary Least Squares or OLS approach (Janie, D. N, 2012) To examine the effect of obedience to traditional leadership (X) on the behavior of the Kurai people in the legislative elections (Y). Data analysis carries in 5 (five) stages, namely: 1) data tabulation, 2) linear regression model estimation, 3) classical assumption testing, 4) model feasibility test (Goodness of Fit Model), 5) linear regression model interpretation.

\section{Traditional Leadership in the Kurai Community}

The Kurai people are the original inhabitants of Bukittinggi Town. The Kurai people have lived and occupied Bukittinggi Town for generations before immigrants from other areas settled in the city. The Kurai community is part of the Minangkabau community. Although the Kurai people live in an urban environment mingling with immigrants from other areas, they still adhere to Minangkabau customs. As is true in Minangkabau society, which is known as the Minangkabau customary adage, "Adat bansadi syarak, syarak basandi kitabullah". That means Islamic law is the foundation of Minangkabau customs, while Al-Qur'an foundation Islamic law. By Minangkabau custom, traditional leadership in the Kurai Bukittinggi community consists of three elements: Ninik mamak, alim ulama, and cadiak pandai.

Ninik mamak is a tribal leader whom tribal members in the Kurai community traditionally elect. Alim ulama is leadership formed naturally in the Kurai community or Minangkabau society in general. The leadership of alim ulama based on election results is recognized by the community naturally as leaders because of their level of understanding and practice of the teachings of Islam. In comparison, cadiak 
pandai is community leadership because it is considered to have advantages because of education, knowledge, or experience.

Based on descriptive data analysis, it shows that the obedience of the Kurai community to the three elements of traditional leadership is still vital, although the level of obedience varies. The results of data analysis in table 1 show that most (177 people or $44.9 \%$ ) respondents are reluctant and obedient to the leadership of ninik Mamak. Meanwhile, the level of obedience to cadiak pandai and alim ulama leadership is relatively almost the same, about 113 people (28.7\%) and 104 people (26.4\%). The results of data analysis in table 1 show that the Kurai Bukittinggi people are still reluctant and obedient to their traditional leaders. Nevertheless, the most respected and respected traditional leadership is the leader of ninik mamak.

Table 1. The composition Respondent based on The degree of respect and obedience to traditional leadership

\begin{tabular}{|c|c|c|c|c|c|}
\hline \multicolumn{2}{|c|}{} & Frequency & Percent & $\begin{array}{c}\text { Valid } \\
\text { Percent }\end{array}$ & $\begin{array}{c}\text { Cumulative } \\
\text { Percent }\end{array}$ \\
\hline \multirow{7}{*}{ Valid } & Alim Ulama & 104 & 26,4 & 26,4 & 26,4 \\
\cline { 2 - 6 } & $\begin{array}{c}\text { Cadiak } \\
\text { Pandai }\end{array}$ & 113 & 28,7 & 28,7 & 55,1 \\
\cline { 2 - 6 } & $\begin{array}{c}\text { Niniak } \\
\text { Mamak }\end{array}$ & 177 & 44,9 & 44,9 & 100,0 \\
\cline { 2 - 6 } & Total & 394 & 100,0 & 100,0 & \\
\hline
\end{tabular}

Resource: Result statistical analysis from data primer.

\section{The Effect Of Traditional Leadership On Voting Behavior}

Before explaining the influence of traditional leadership on voting behavior, previously explained the degree of obedience of the Kurai community to traditional leadership. The results of data analysis in table 2 show that traditional leadership has a strong influence on the Kurai community of Bukittinggi, which is $84.3 \%$. The results of data analysis show that traditional leadership consisting of ninik mamak, cadiak pandai, and alim ulama still has a significant influence on the lives of the Kurai people. It is evident from the results of data analysis in table 3 that the degree of community compliance with traditional leadership is still substantial. Data in table 3 shows that the Kurai community's degree of compliance with traditional leadership is a majority or 84.3 percent substantial. The strengthens the reason for carrying out further analysis using linear regression.

Table 2. Degree of obedience respondent to traditional leadership

\begin{tabular}{|c|c|c|c|c|}
\hline \multicolumn{2}{|c|}{$\begin{array}{c}\text { The degree of people } \\
\text { obedience }\end{array}$} & Frequency & Percent & Valid Percent \\
\hline \multirow{2}{*}{1} & Strong & 333 & 84,3 & 84,3 \\
2 & Currently & 7 & 1,8 & 1,8 \\
3 & Weak & 54 & 13,9 & 13,9 \\
\cline { 2 - 5 } & Total & 394 & 100,0 & 100,0 \\
\hline
\end{tabular}

Source: Result from statistical analysis data

The classical assumptions were tested before the linear regression analysis, namely normality, heteroscedasticity, and multicollinearity, and the model's fit test.

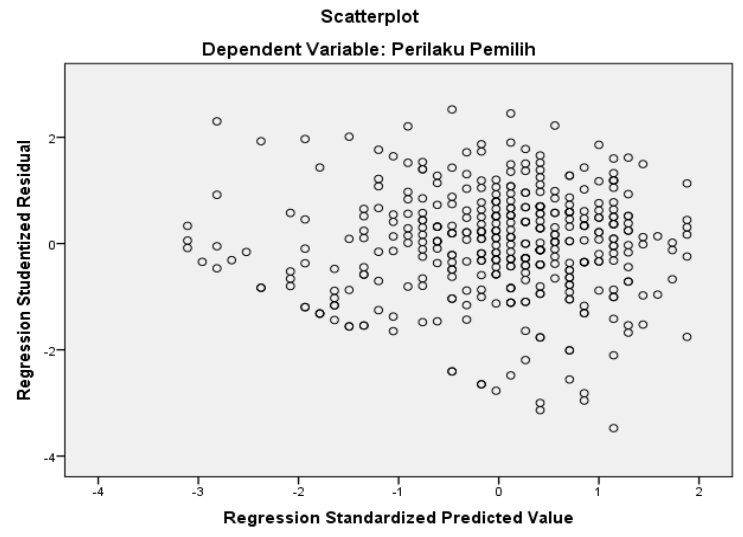

Figure 1. Regression Standardized Predicted Value

Data in Figure 1. The scatter plot graph shows that the distribution of points does not form a specific pattern/flow. Thus the data on the graph shows that there is no heteroscedastic problem.

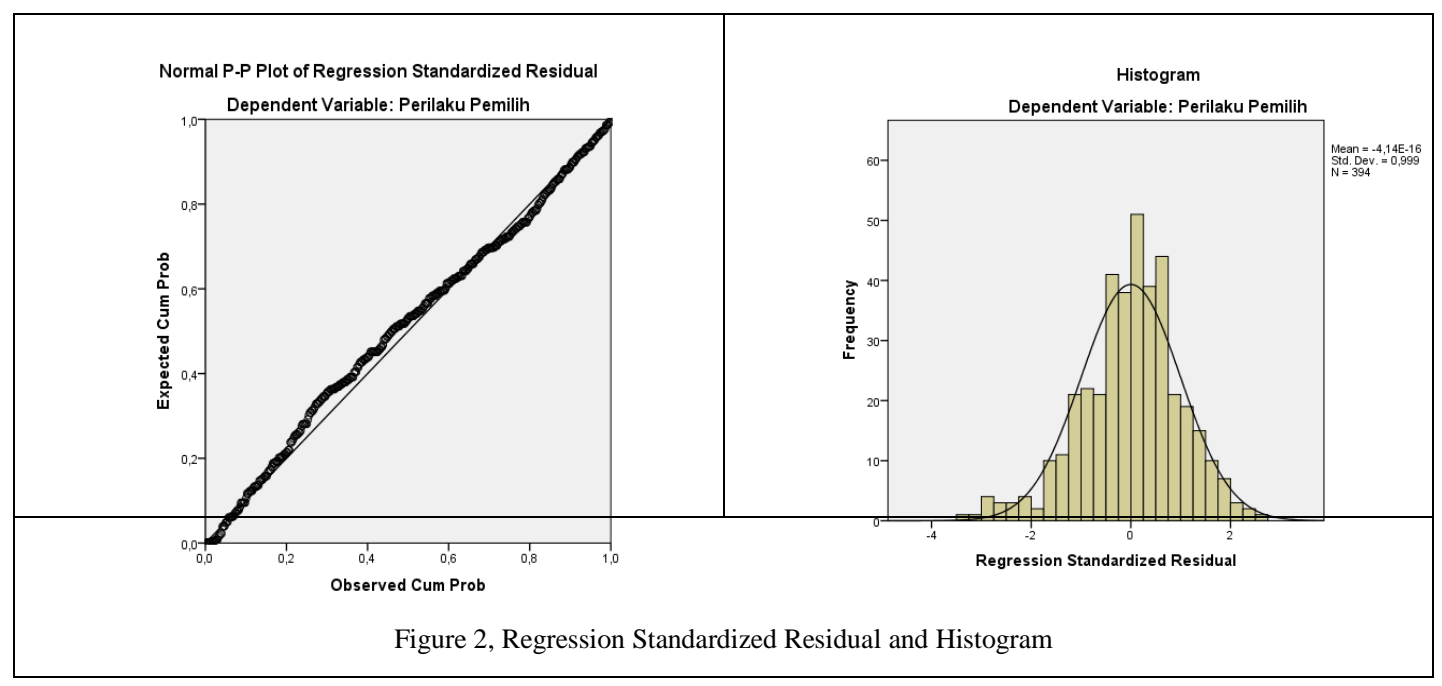


The distribution of the points from Figure 2 regarding the Standardized Residual Regression is relatively close to a straight line, so it concluded that the residual (data) is usually distributed. The data on the histogram also shows the same thing. These results align with the classical assumption of linear regression with the OLS approach, namely normality.

\begin{tabular}{|c|c|c|c|c|c|c|}
\hline \multicolumn{7}{|c|}{ Table 3. ANOVA $^{\mathrm{a}}$} \\
\hline \multicolumn{2}{|c|}{ Model } & $\begin{array}{c}\text { Sum of } \\
\text { Squares }\end{array}$ & Df & $\begin{array}{c}\text { Mean } \\
\text { Square }\end{array}$ & F & Sig. \\
\hline \multirow{3}{*}{1} & $\begin{array}{c}\text { Regress } \\
\text { ion }\end{array}$ & 14379,308 & 1 & 14379,308 & $\begin{array}{c}268,9 \\
14\end{array}$ &, $000^{\mathrm{b}}$ \\
\cline { 2 - 7 } & $\begin{array}{c}\text { Residua } \\
1\end{array}$ & 20960,926 & 392 & 53,472 & & \\
\cline { 2 - 7 } & Total & 35340,234 & 393 & & & \\
\hline \multicolumn{7}{|c|}{ a. Dependent Variable: Voters Behavior } \\
\hline \multicolumn{7}{|c|}{} \\
\cline { 2 - 7 }
\end{tabular}

The fittest of the model is explained as follows: the results of the $\mathrm{F}$ test explain that value. The calculated $\mathrm{F}$ (sig.) in the table above is 0.000 or less than the 0.05 significance level. So it can be concluded that the linear regression model estimated in this study is appropriate to explain the effect of obedience to traditional leadership (X) on the dependent variable of the voting behavior of the Kurai indigenous people in the 2014 legislative elections (Y).

The t-test results explain that the effect of the variable obedience to traditional leadership (X) on the erratic behavior of the Kurai people shows the value of probability count sig. $(0.000)$ which is smaller than 0.05 , so it can be stated that the traditional leadership variable significantly affects voting behavior at 5\% alpha. In other words, traditional leadership significantly affects voting behavior at the $95 \%$ confidence level.

Tabel 4 Coefficients

\begin{tabular}{|c|c|c|c|c|c|c|}
\hline & \multirow[t]{2}{*}{ Model } & \multicolumn{2}{|c|}{$\begin{array}{l}\text { Unstandardized } \\
\text { Coefficients }\end{array}$} & \multirow{2}{*}{$\begin{array}{c}\begin{array}{c}\text { Standardi } \\
\text { zed } \\
\text { Coefficie } \\
\text { nts }\end{array} \\
\text { Beta }\end{array}$} & \multirow[t]{2}{*}{$\mathrm{t}$} & \multirow[t]{2}{*}{ Sig. } \\
\hline & & B & Std. Error & & & \\
\hline & (Constant) & $-2,603$ & 2,046 & & $-1,272$ & ,204 \\
\hline 1 & $\begin{array}{c}\text { Obedience to } \\
\text { Traditional } \\
\text { Leadership }\end{array}$ & ,887 & ,054 & 638 & $\begin{array}{c}16,39 \\
9\end{array}$ & ,000 \\
\hline
\end{tabular}

a. Dependent Variable: Voting bahavior

The coefficient of determination explains the variation in the effect of the independent variables on the dependent variable. The R-Square value in Table 6 Model Summary, which is 0.407 , shows that the proportion of the variable obedience to traditional leadership on the voting behavior is $40.7 \%$. It means that obedience to traditional leadership has a proportion of influence on the behavior of the Kurai people in the legislative elections of $40.7 \%$.

After the estimation of the linear regression model has been carried out and its fulfillment tested with the classical assumption test and the model feasibility test, the last step is to interpret it. Interpretation or explanation of a model produced in this study can do because all stages of classical assumption test and model feasibility have been fulfilled. Based on the data analysis in table 7, the output of the SPSS Coefficients can be interpreted as a linear regression model (equation) as follows:

$$
\mathrm{Y}=-2.603+0.887 \mathrm{X}
$$

The regression coefficient of obedience to traditional leadership (X) is positive, meaning that the more respondents' compliance with traditional leadership, the more influential it is on the voting behavior of the Kurai indigenous people in the 2014 legislative elections. Based on probability, a hypothesis decision can be made by looking at Table 3 ANOVA and table 4 Coefficients. If the probability $>0.05$, Ho is accepted, and $\mathrm{Ha}$ is rejected. If the probability is $<0.05$, Ho is rejected, and $\mathrm{Ha}$ is accepted. From the results of the significance test in this study, it can be seen that the probability value is 0.00 $(<0.01)$. This result indicates $\mathrm{Ho}$ is rejected and $\mathrm{Ha}$ is accepted. This means that obedience to traditional leadership has been proven to significantly influence voting behavior, in other hand, hypothesis (Ha4) is accepted.

Based on the results of data analysis, it can be stated that traditional leadership influences voting behavior from the Kurai community in the election of legislative members in Bukittinggi Town. The study's results strengthen the findings of a study conducted by Liddle \& Mujani (2007) which examines the influence of political party leadership on community voting behavior in the Indonesian legislative general election in 1999 and the presidential election of 2004. The results show that political party leadership influences voting behavior. The results of this study are also in line with the findings of a study conducted by Curtice \& Hunjan (2006), which used a comparative method carried out in several countries in the general elections for parliamentarians and presidential elections. The results show that the evaluation of political party leadership affects electoral behavior in the presidential election. However, in the election of members of parliament, the influence of the evaluation of political party leadership on voting behavior shows different results due to differences in the party system adopted by a country. In the two-party system, the evaluation of political party leadership has a significant effect on voting behavior. However, in a multi-party system, the evaluation of political party leadership has little effect on voting behavior.

The results of this study are also in line with the results of Susilo Utomo's (2009) study in the 2008 Central Java regional head election. This study showed that local leadership affected voting behavior. Furthermore, the results of this study also support the results of Graefe (2013) in the election of the President of the United States, which show that the ability to overcome crises and leadership abilities shown during the campaign affect voting behavior. Another study conducted by Garzia \& Ferreira da Silva (2021), a comparative study in several Western democracies, shows that 
political party leaders who have dominant power in political parties strongly influence voting behavior. Therefore, party leaders try to strengthen their position in political parties to capitalize on the potential to be elected in elections effectively. The latest study conducted by Khan, Jawad, Shah, Sarir, \& Khan (2021) in the general election in Khyber Pakhtunkhwa District Dir Upper Pakistan also shows the influence of political party leadership on voting behavior in traditional societies.

\section{CONCLUSION}

Based on the analysis results and discussion with other research findings, several things can be concluded. First, the level of obedience of the community to their traditional leaders is intense. Second, traditional leadership influences the people's political behavior in the general election. The results of this study prove that obedience to traditional leadership affects customs and culture and has an impact on political behavior. This is evidenced by the results of research showing that traditional leadership influences voting behavior in general elections. This study contributes to previous studies that concluded that leadership influences voting behavior in general elections. The results of this study also show that the leadership factor is essential in the life and culture of the community, including in the political field.

\section{RECOMMENDATION}

The result of this study is that the traditional leadership community of Minangkabau in West Sumatera positively impacts voting elections at general elections. The limitation of this study is that this study did not analyze the impact of separated elements of traditional leadership such ninik mamak, alim ulama, and cadiak pandai on voting behavior at general elections. So this study could not inform which element the traditional leadership gives the most substantial impact voting behavior at the general election. Therefore it is recommended that the following study research analysis impact elements of traditional leadership Minangkabau culture such as ninik mamak, alim ulama, aan cadiak pandai on voting behavior at the general election.

\section{REFERENCE}

[1] Adnan, M. Fachri (2013). The Influence of Candidate Quality and Campaign Issues on Voting Behavior at the GovernorEelection of West Sumatra Indonesia, TINGKAP Vol. IX No. 2 Th. 2013, Universitas Negeri Padang, hal.167-177

[2] Amri, A., Ramdani, Z., Warsihna, J., \& Tae, L. F. (2021). Tungku Tigo Sajarangan, Tali Tigo Sapilin: A Strategy Towards World Class University Based on Local Wisdom Perspective. ALISHLAH: Jurnal Pendidikan, 13(1), 31-40. STAI Hubbulwathan Duri.

[3] Antunes, R. (2010). Theoretical models of voting behavior. Exedra, 4, 145-170.

[4] Conner, T. W. (2014). Exploring voting behavior on American Indian legislation in the United States Congress. Social Science Journal, 51(2), 159-166. Elsevier Inc.

[5] Curtice, J., \& Hunjan, S. (2006). The Impact of Leadership Evaluations on Voting Behaviour: Do the Rules Matter? Centre for Research into Elections and Social Trends (CREST) working paper, (110), 14-19.

[6] Fauzi, A. M., Mudzakir, M., \& Abdulrahim, M. O. (2019). Social
Conflict In Contestation Of Indonesia Election. The Journal of Society and Media, 3(2), 159. Universitas Negeri Surabaya.

[7] Fitri, R., Adnan \& Adnan, (2019). Peranan Kepemimpinan Alim Ulama Dalam Meningkatkan Partisipasi Pemilih Pada Pilkada Di Kota Padang Panjang, . Retrieved from www.kpusumbarprov.go.id

[8] Fitriyah, 2013, Perilaku Pemilih Dalam Pilkada Kabupaten Kudus 2013, . Jurnal Politika, Vol 4 No. 2

[9] Garzia, D., \& Ferreira da Silva, F. (2021). Negative personalization and voting behavior in 14 parliamentary democracies, 1961-2018. Electoral Studies, 71. Elsevier Ltd.

[10] Graefe, A. (2013). Issue and leader voting in U.S. presidential elections. Electoral Studies, 32(4), 644-657.

[11] Heath, O., Verniers, G., \& Kumar, S. (2015). Do Muslim voters prefer Muslim candidates? Co-religiosity and voting behaviour in India. Electoral Studies, 38, 10-18. Elsevier Ltd.

[12] Kareem, A. O., Oshungade, I. O., \& Oyeyemi, G. M. (2015). A Note on the Precision of Stratified Systematic Sampling. Open Journal of Statistics, 05(02), 104-112.

[13] Khan, N., Jawad, M., Shah, M., Sarir, S., \& Khan, N. (2021). A Sociological Analysis Of Party Leadership Influencing Voting Behavior In Traditional Communities Of Khyber Pakhtunkhwa DISTRICT DIR UPPER. Humanities \& Social Sciences Reviews, 9(2), 160-166. GIAP Journals.

[14] Kurniawan, F., Adnan, M. F., \& Alhadi, Z. (2020). Efektivitas Kepemimpinan Tungku Tigo Sajarangan Dalam Pembangunan Nagari di Kenagarian Lingkuang Aua. the islamic , 2(2), 123-131.

[15] Latif, A., Mustanir, A., \& Irwan, I. (2019). Pengaruh Kepemimpinan Terhadap Partisipasi Masyarakat Pada Perencanaan Pembangunan. JAKPP (Jurnal Analisis Kebijakan \& Pelayanan Publik), (March 2020), 144-164.

[16] Liddle, R. W., \& Mujani, S. (2007). Leadership, party, and religion: Explaining voting behavior in Indonesia. Comparative Political Studies, 40(7), 832-857.

[17] Nasution, R. D. (2017). Kyai Sebagai Agen Perubahan Sosial Dan Perdamaian Dalam Masyarakat Tradisional. Sosiohumaniora, 19(2), 177-184.

[18] Pillai, R., Williams, E. A., Lowe, K. B., \& Jung, D. I. (2003). Personality, transformational leadership, trust, and the 2000 U.S. presidential vote. Leadership Quarterly, 14(2), 161-192. Elsevier Inc.

[19] Pratama, I. S., Bachriar, M., \& Fitriani, R. (2017). Peranan tungku tigo sajarangan dalam mengatasi perkawinan sesuku menurut hukum adat di nagari sungai buluah Kab.Padang Pariaman. JOM Fakultas Hukum, 4(1).

[20] Ratna Wijayanti, M. (2016). Pengaruh kepemimpinan islami, motivasi dan kepuasan kerja terhadap kinerja karyawan dengan lama kerja sebagai variabel moderating. Jurnal PPKM III, 3(3), $185-192$.

[21] Stanley, B. (2011). Populism, nationalism, or national populism? An analysis of Slovak voting behaviour at the 2010 parliamentary election. Communist and Post-Communist Studies, 44(4), 257270. Elsevier Ltd. Retrieved from http://dx.doi.org/10.1016/j.postcomstud.2011.10.005

[22] Juri, Sugianto (2020), Ananilis Perilaku Pemilih Di Kelurahan Kedabang Kecamatan Sintang Pada Pemilihan Umum Presiden Dan Wakil Presiden Tahun 2019, Jurnal Pendidikan Kewargenagaraan, Vol. 5 No. 2. Hal. 30-38

[23] Susilo Utomo. (2009). Kepemimpinan Lokal Era Pilkada Langsung. Jurnal Ilmu Sosial, Vol. 8 No. 1. Hal. Hal.30-47

[24] Sesmiarni, Zulfani, et al (2018), The Islamic Education Strategies in Local Culture, Perspective of West Sumatra Society, Jurnal Ducative, Vol. 3 No. 1.

[25] Tigue, C. C., Borak, D. J., O'Connor, J. J. M., Schandl, C., \& Feinberg, D. R. (2012). Voice pitch influences voting behavior. Evolution and Human Behavior, 33(3), 210-216. Elsevier B.V. Retrieved from http://dx.doi.org/10.1016/j.evolhumbehav. 2011.09.004

[26] Vizcaíno-González, M., Pineiro-Chousa, J., \& López-Cabarcos, M. Á. (2016). Analyzing the determinants of the voting behavior using a genetic algorithm. European Research on Management and Business Economics, 22(3), 162-166. European Academy of 
Management and Business Economics.

[27] Williams, E. A., Pillai, R., Deptula, B., \& Lowe, K. B. (2012). The effects of crisis, cynicism about change, and value congruence on perceptions of authentic leadership and attributed charisma in the
2008 presidential election. Leadership Quarterly, 23(3), 324-341.

[28] Yukl, G. (2012). Effective leadership behavior: What we know and what questions need more attention. Academy of Management Perspectives, 26(4), 66-85. 